\title{
Synthesis of New C,C-Linked Bipyrazole and Comparative Theoretical Calculations
}

\author{
IBRAHIM BOUABDALLAH ${ }^{1,2,}{ }^{*}$ ISMAIL ZIDANE ${ }^{2}$, RACHID TOUZANI ${ }^{3}$, FOUAD \\ MALEK $^{1}$, ABDELKRIM RAMDANI $^{1}$, ABRAHAM F. JALBOUT $^{4}$ and B. TRZASKOWSKI ${ }^{4}$
}

${ }^{1}$ Laboratoire de Chimie Organique, Macromoléculaire et Produit Naturels, Faculté des

Sciences, Université Mohammed I ${ }^{\mathrm{er}}$, BP 524, 60000 Oujda, Maroc

${ }^{2}$ Centre Régionale des Métiers d'Education et de Formation,

Région d'orientale, Maroc

${ }^{3}$ Faculté Pluridisciplinaire, Université Mohammed I ${ }^{\text {er }}$, B.P. 300, 62700 Selouane, Nador, Maroc

${ }^{4}$ NASA Astrobiology Centers, Department of Chemistry, University of Arizona, Tucson, AZ 85721, USA

bouabib2002@yahoo.fr

Received 29 June 2012 / Accepted 30 August 2012

\begin{abstract}
New C,C-linked bipyrazole 1,1'-di(4-aminophenyl)-5,5'-diisopropyl-3,3'-bipyrazole (2) has been synthesized and characterized. Theoretical calculations have been carried out on target 2 and literature $1 C, C$-linked bipyrazoles to compare with reported results. All calculations were carried out with the AM1 level of theory using the GAUSSIAN 03. The nature of substituent attached to the pyrazolic nitrogen has an effect on the thermodynamic variable values. The mono and bis $N$-substituted $C, C$-linked bipyrazoles have different thermodynamic properties.
\end{abstract}

Keywords: $C, C$-Linked, Bipyrazole, Theoretical calculation, Mono and bis $N$-substituted

\section{Introduction}

In the literature, pyrazole derivatives have been the subject of several studies. They have been used as potential anti-inflammatory agents ${ }^{1}$, cytotoxic agents $^{2}$, insecticides ${ }^{3}$, herbicides $^{4}$ and fungicides ${ }^{5}$. Pyrazole nucleis can be associated in different ways ${ }^{6}$ and lead to several carbonaceous skeletons type: tripod, bipyrazole, macrocycle. During last years, many tripods with pyrazolic units and C,C-linked bipyrazole derivatives have been prepared in our laboratory ${ }^{7-14}$ for several purposes such as liquid-liquid extraction ${ }^{15}$, catalysis $^{16}$, corrosion inhibition ${ }^{17}$, anticancer ${ }^{18}$, resins ${ }^{19}$ and polymers ${ }^{20}$ synthesis. As part of our laboratory research programme we propose in the present paper to synthesize and characterize a new C,C-linked bipyrazole type 1,1'-di(4-aminophenyl)-5,5'-diisopropyl3,3'-bipyrazole 2 (Figure 1). In order to get better understanding about the characteristic properties of these $C, C$-linked bipyrazole 
compounds, we have calculated some thermodynamic quantities of the new material 2 and literature compound $\mathbf{1}$. The mono and bis $N$-substitution effect of $C, C$-linked bipyrazoles towards thermodynamic variable values have examined.<smiles>[R1]n1nc(-c2cc(C(C)C)n([R2])n2)cc1C(C)C</smiles>

$1: \mathrm{R} 1=\mathrm{p}-\mathrm{NO}_{2}-\mathrm{C}_{6} \mathrm{H}_{4} ; \mathrm{R} 2=\mathrm{p}-\mathrm{NO}_{2}-\mathrm{C}_{6} \mathrm{H}_{4} \quad 3: \mathrm{R} 1=\mathrm{p}-\mathrm{NO}_{2}-\mathrm{C}_{6} \mathrm{H}_{4} ; \mathrm{R} 2=\mathrm{H}$

$2: \mathrm{R} 1=\mathrm{p}-\mathrm{NH}_{2}-\mathrm{C}_{6} \mathrm{H}_{4} ; \mathrm{R} 2=\mathrm{p}-\mathrm{NH}_{2}-\mathrm{C}_{6} \mathrm{H}_{4} \quad 4: \mathrm{R} 1=\mathrm{CH}_{2}-\mathrm{CO}_{2} \mathrm{Et} ; \mathrm{R} 2=\mathrm{H}$

Figure 1. Structure of new 2 and investigated 1, 3, 4 compounds

\section{Experimental}

Melting points were determined in open glass capillaries using BUCHI 510 Melting Point apparatus and are uncorrected. The infrared (IR) spectra were recorded on PERKIN-ELMER 1310 infrared spectrophotometer using the $\mathrm{KBr}$ disc technique. ${ }^{1} \mathrm{H}$ and ${ }^{13} \mathrm{C}$ NMR spectra were recorded on BRUKER 300 (operating at $300 \mathrm{MHz}$ for ${ }^{1} \mathrm{H}$ ) spectrometer. Chemical shifts are listed in ppm and reported relative to tetramethylsilane (TMS). Mass spectra were obtained on a VG7070E spectrometer.

\section{Synthesis of 1,1'-di(4-aminophenyl)-5,5'-diisopropyl-3,3'-bipyrazole (2)}

To a mixture of 1,1'-di(4-nitrophenyl)-5,5'-diisopropyl-3,3'-bipyrazole $(0.1 \mathrm{mmol})$ and granulated tin $(0.3 \mathrm{mmol})$ was added concentrated hydrochloric acid $(0.1 \mathrm{~mL})$. The mixture was refluxed for one hour and cooled to room temperature. The solution was neutralized by sodium hydroxide solution. The precipitate was collected by filtration and recrystalized to give pure 1,1'di(4-aminophenyl)-5,5'-diisopropyl-3,3'-bipyrazole (2). Yield : 95\%; $\mathrm{R}_{\mathrm{f}}: 0.3$ (Alumine / $\left.\mathrm{CH}_{2} \mathrm{Cl}_{2}\right)$; m. p. : $>260{ }^{\circ} \mathrm{C} ;{ }^{1} \mathrm{H}-\mathrm{NMR}\left(300 \mathrm{MHz}, \mathrm{DMSO}-\mathrm{d}_{6}, \delta, \mathrm{ppm}\right): 7.05\left(\mathrm{~d}, 4 \mathrm{H}, \underline{\mathrm{H}} 2{ }^{\prime}, \mathrm{J}=8.7\right.$ $\mathrm{Hz}), 6.63$ (d, $\left.4 \mathrm{H}, \underline{\mathrm{H}} 3^{\prime}, \mathrm{J}=8,4 \mathrm{~Hz}\right), 6.43(\mathrm{~s}, 2 \mathrm{H}, \mathrm{C} 4-\underline{\mathrm{H}}), 5.38\left(\mathrm{~s}, 4 \mathrm{H}, \mathrm{NH}_{2}\right), 2.88(\mathrm{~m}, 2 \mathrm{H}$, $\left.\mathrm{C} \underline{\mathrm{H}}\left(\mathrm{CH}_{3}\right)_{2}, \mathrm{~J}=6.9 \mathrm{~Hz}\right), 1.10\left(\mathrm{~d}, 12 \mathrm{H}, \mathrm{CH}\left(\mathrm{C}_{3}\right)_{2}, \mathrm{~J}=6.6 \mathrm{~Hz}\right) ;{ }^{13} \mathrm{C}-\mathrm{NMR}(75 \mathrm{MHz}, \mathrm{DMSO}-$ $\left.\mathrm{d}_{6}, \delta, \mathrm{ppm}\right): 151.5$ (C3), 149.6 (C4'), 145.9 (C5), 128.9 (C1'), 127.6 (C2'), 114.3 (C3'), 100.1 (C4), $25.8\left(\underline{\mathrm{CH}}\left(\mathrm{CH}_{3}\right)_{2}\right), 23.4\left(\mathrm{CH}\left(\mathrm{CH}_{3}\right)_{2}\right)$; IR $\left(\mathrm{KBr}\right.$ disk, $\left.\mathrm{cm}^{-1}\right): 3490,3320,3200\left(v_{\mathrm{N}-\mathrm{H}}\right)$, $2980\left(v_{\mathrm{C}-\mathrm{H}, \mathrm{CH} 3}\right), 2930\left(v_{\mathrm{C}-\mathrm{H}, \mathrm{CH}(\mathrm{CH} 3) 2}\right), 1650\left(v_{\mathrm{C}=\mathrm{N}}\right), 1610\left(v_{\mathrm{C}=\mathrm{C}}\right), 1530,1340,1320,1190,1100,960$, $850,820,700\left(\delta_{\mathrm{NH} 2}\right) ; \mathrm{MS}(\mathrm{EI}), \mathrm{m} / \mathrm{z}: 400,385,371,318,264,239,200,185,131,92,65,43$; Anal. Calcd for $\mathrm{C}_{24} \mathrm{H}_{28} \mathrm{~N}_{6}$ : C 71.97, H 7.05, N 20.98, Found: C 71.82, H 7.00, N 20.93

\section{Results and Discussion}

\section{Synthesis}

Compounds 1,3-6 (Scheme 1) were prepared according to the literature procedure ${ }^{14,21}$. The new C,C-linked bipyrazole 1,1'-di(4-aminophenyl)-5,5'-diisopropyl-3,3'-bipyrazole (2) was synthesized by reduction of nitro moiety in compound 1 . This reaction was carried out using granulated tin in refluxing concentrated hydrochloric acid to afford pure product $\mathbf{2}$ in excellent yield (95\%).

\section{Characterization}

In the ${ }^{1} \mathrm{H}-\mathrm{NMR}$ spectra of diamine 2 recorded in DMSO- $\mathrm{d}_{6}$ appears two signals at 1.10 and $2.88 \mathrm{ppm}$, corresponding respectively to the underline protons of $\mathrm{CH}\left(\mathrm{CH}_{3}\right)_{2}$ and $\mathrm{C} \underline{\mathrm{H}}\left(\mathrm{CH}_{3}\right)_{2}$. As shown in Table 1 all signals are shielded to high fields by the mesomeric effect of the 
amino groups linked to the benzene rings. The coupling constants between the benzylic protons in compounds $\mathbf{1}$ and $\mathbf{2}$ are remaining unchanged and take a value of $10.3 \mathrm{ppm}$ in $\mathbf{3}$. The similar finding was observed between the methylic and methylinic protons, due to the negligible effect of the nitro and amino moieties.

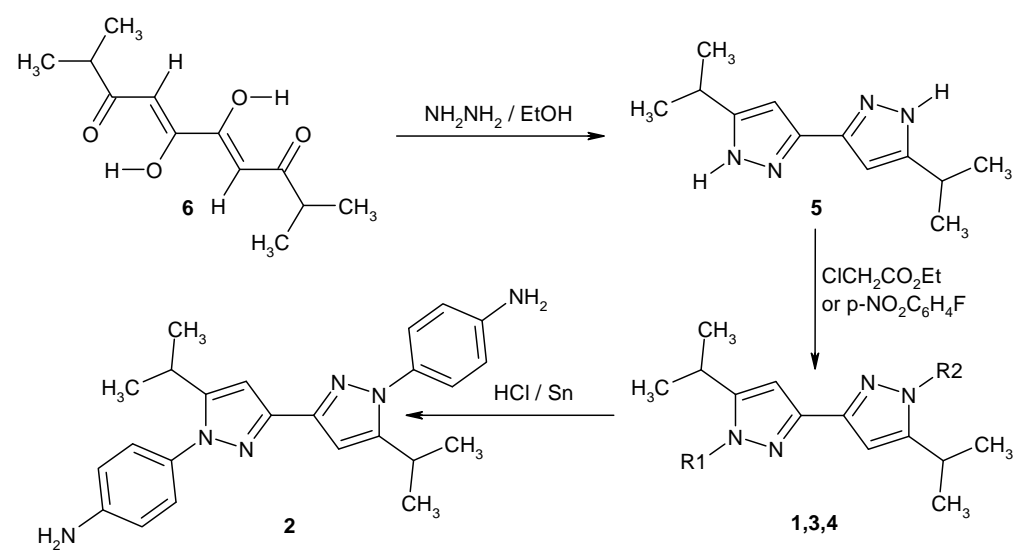

Scheme 1. Synthesis of 1,1'-di(4-aminophenyl)-5,5'-diisopropyl-3,3'-bipyrazole

Table 1. Comparative studies between chemical shifts of target 2 and literature 1, 3-6 compounds

\begin{tabular}{cccccccc}
\hline Entry & ${ }^{\mathrm{a}} \delta\left(\mathrm{CH}\left(\mathrm{CH}_{3}\right)_{2}\right)$ & ${ }^{\mathrm{a}} \delta\left(\mathrm{C} \underline{\mathrm{H}}\left(\mathrm{CH}_{3}\right)_{2}\right)$ & ${ }^{\mathrm{a}} \delta(\mathrm{C} 4-\underline{\mathrm{H}})$ & ${ }^{\mathrm{a}} \delta\left(\mathrm{C}-\underline{\mathrm{H}} 2{ }^{\prime}\right)$ & ${ }^{\mathrm{a}} \delta\left(\mathrm{C}-\underline{\mathrm{H}}_{3}{ }^{\prime}\right)$ & ${ }^{\mathrm{b}} \mathrm{J}_{\mathrm{H} 2}{ }^{\prime}-\mathrm{H}_{3}$, & ${ }^{\mathrm{b}} \mathrm{J}_{\mathrm{HC}-\mathrm{CH} 3}$ \\
\hline $\mathbf{1}$ & 1.25 & 3.15 & 6.76 & 7.70 & 8.35 & 8.7 & 6.9 \\
$\mathbf{2}$ & 1.10 & 2.88 & 6.43 & 7.05 & 6.63 & 8.7 & 6.9 \\
$\mathbf{3}$ & $1.25-1.34$ & $2.99-3.17$ & $6.47-$ & 7.70 & 8.35 & 10.3 & $7.8-8.4$ \\
$\mathbf{4}$ & 1.24 & $2.87-3.01$ & 6.36 & -- & -- & -- & $6.9-6.9$ \\
$\mathbf{5}$ & 1.24 & 2.91 & 6.25 & -- & -- & -- & 7.9 \\
$\mathbf{6}$ & 1.24 & 2.72 & -- & -- & -- & -- & 6.9 \\
\hline
\end{tabular}

${ }^{a}$ Chemical shifts are listed in ppm and are reported relative to TMS. ${ }^{b}$ Coupling constants are $\mathrm{Hz}$

In symmetrical molecules $(\mathbf{1}, \mathbf{2}, 5,6){ }^{1} \mathrm{H}$ and ${ }^{13} \mathrm{C}$ NMR spectra show single peaks. Whereas in the mono $N$-substituted bipyrazoles $(4,5)$, results illustrate two types of peaks assigned to the methylic, methylinic and pyrazolic protons. However for the $N$-substituted compound 4, where the pyrazolic ring is linked to $\mathrm{CH}_{2} \mathrm{CO}_{2} \mathrm{CH}_{2} \mathrm{CH}_{3}$ moiety, we have noted in ${ }^{1} \mathrm{H}-\mathrm{NMR}$ that only the methylinic protons are duplicated. Indeed, for the first $\left[\mathrm{CH}\left(\mathrm{CH}_{3}\right)_{2}\right]$ the superposition of methylic protons peaks belonging to both isopropyl and ethyl groups gives a multiplet. Also, the asymmetry does not influences the pyrazolic protons chemical shifts.

The IR spectra of compound 2 showed that the absorption peaks corresponding to the stretching vibration of the nitro group disappeared, showing that the $\mathrm{NO}_{2}$ moiety in 1,1 '-di (4-nitrophenyl)-5,5'-diisopropyl-3,3'-bipyrazole 1 had participated completely in the reduction reaction. Also, the bands at 1650 and $1610 \mathrm{~cm}^{-1}$ was attribuate to vibration of $\mathrm{C}=\mathrm{N}$ and $\mathrm{C}=\mathrm{C}$ bonds of the pyrazolic and benzenic rings. The mass spectrum displayed a molecular ion peak at $\mathrm{m} / \mathrm{z} 400(100 \%)$. The new compound is very stable at room temperature and presents a higher melting point $\left(>260{ }^{\circ} \mathrm{C}\right)$. Several analysis methods IR, ${ }^{1} \mathrm{H}$ NMR and $\quad{ }^{13} \mathrm{C}$ NMR spectroscopy, mass spectrometry and elemental analysis data are consistent with the formulation indicated in Scheme 1. 


\section{Theoretical calculations}

All calculations in this work were carried out with the AM1 level of theory using the GAUSSIAN $03^{22}$ suite of programs. In addition we have carried out using AM1 optimizations and frequency calculations. More information about these methods is available elsewhere ${ }^{23}$. Figure 2 presents the optimized structure of the molecule with bond lengths and bond angles. Table 2 shows the thermodynamic properties for the $C, C$-linked bipyrazoles in Figure 2 where $\mathrm{T}$ (temperature in $\mathrm{K}$ ), $\mathrm{S}$ (entropy in $\mathrm{J} \mathrm{mol}^{-1} \mathrm{~K}^{-1}$ ), Cp (heat capacity at constant pressure in $\mathrm{kJ} \mathrm{mol}^{-1} \mathrm{~K}^{-1}$ ) and $\Delta \mathrm{H}=\mathrm{H}^{\circ}$ - $\mathrm{H}^{\circ} 298.15$ (enthalpy content, in $\mathrm{kJ} \mathrm{mol}^{-1}$ ), $\mathrm{T} 1=100 \mathrm{~K}, \mathrm{~T} 2=298.15 \mathrm{~K}$ and T3 $=1000 \mathrm{~K}$ calculated AM1 frequencies. The fits were performed according to the equations implemented by the National Institute of Standards and Technology $y^{24}$. These equations have been very good at predicting physical properties of various molecules, as we have tested in the past. ${ }^{21,25-27}$.

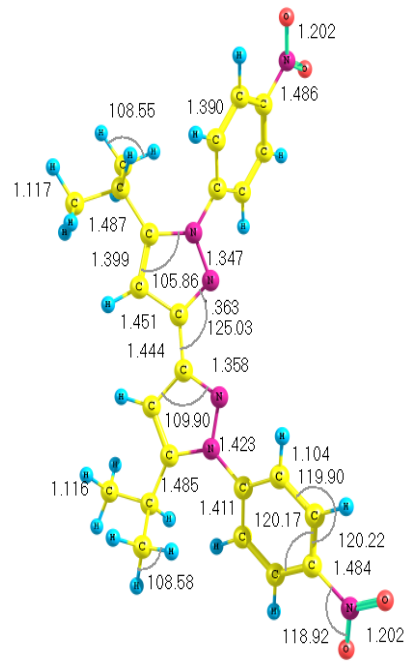

1

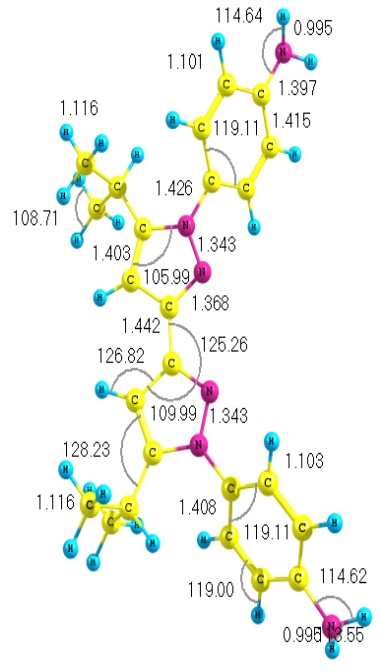

2

Figure 2. AM1 optimized structure, where bond lengths are in angstroms $(\AA)$ and bond angles in degrees $\left(^{\circ}\right)$ for $\mathbf{1}$ and $\mathbf{2}$

Table 2. Thermodynamic properties for the species $\mathbf{1}$ and $\mathbf{2}$

\begin{tabular}{|c|c|c|c|c|c|}
\hline & & Fitted Thermodynamic Equation $(\mathrm{T} / 1000=\mathrm{t})$ & $\mathrm{T}_{1}$ & $\mathrm{~T}_{2}$ & $\mathrm{~T}_{3}$ \\
\hline \multirow{3}{*}{1} & $\mathrm{~S}$ & $\begin{array}{c}-58.87173 * \ln (\mathrm{t})+1992.17868 * \mathrm{t}- \\
1003.68515 * \mathrm{t}^{2} / 2+123.24467 \mathrm{t}^{3} / 3-0.92806 /\left(2 * \mathrm{t}^{2}\right) \\
+196.99856\end{array}$ & 480.40 & 813.66 & 1728.06 \\
\hline & $\mathrm{C}_{\mathrm{p}}$ & $\begin{array}{c}26.99605+1569.32847 * \mathrm{t}-353.05153 * \mathrm{t}^{2}- \\
187.61894 * \mathrm{t}^{3}+0.18916 * \mathrm{t}^{-2}\end{array}$ & 200.16 & 457.39 & 1060.75 \\
\hline & $\Delta \mathrm{H}$ & $\begin{array}{c}-93.45601 * \mathrm{t}+2164.77461 * \mathrm{t}^{2} / 2- \\
1287.66867 * \mathrm{t}^{3} / 3+273.03726 * \mathrm{t}^{4} / 4-1.26606\end{array}$ & 12.32 & 77.28 & 650.65 \\
\hline \multirow{3}{*}{2} & $\mathrm{~S}$ & $\begin{array}{c}-65.19197 * \ln (\mathrm{t})+2037.87589 * \mathrm{t}-1050.2049 * \mathrm{t}^{2} / 2 \\
+136.08601 \mathrm{t}^{3} / 3-0.95834 /\left(2 * \mathrm{t}^{2}\right)+177.24856\end{array}$ & 478.03 & 813.05 & 1735.01 \\
\hline & $\mathrm{C}_{\mathrm{p}}$ & $\begin{array}{c}-43.93648+1968.08342 * \mathrm{t}-991.51002 * \mathrm{t}^{2}+ \\
131.43787 * \mathrm{t}^{3}+0.57896 * \mathrm{t}^{-2}\end{array}$ & 200.51 & 461.31 & 1066.38 \\
\hline & $\Delta \mathrm{H}$ & $\begin{array}{c}-98.51156 * \mathrm{t}+2204.12039 * \mathrm{t}^{2} / 2- \\
1323.76625 * \mathrm{t}^{3} / 3+280.41761 * \mathrm{t}^{4} / 4-1.2862\end{array}$ & 12.24 & 77.59 & 655.50 \\
\hline
\end{tabular}


Compound 1 presents the thermodynamic variable values slightly lower than those described for the regioisomer $\mathbf{I}$ in 1,1'-di(2-nitrophenyl)-5,5'-dipropyl-3,3'-bipyrazole ${ }^{28}$. In the optimized structure, the $\mathrm{N}\left(\mathrm{NH}_{2}\right)-\mathrm{C}$ bond length of $1.397 \AA$ in 2 is shorter than the $\mathrm{N}\left(\mathrm{NO}_{2}\right)-\mathrm{C}$ of $1.486 \AA$ in $\mathbf{1}$. This difference can be explained by the force applied by the nitro and amino groups.

\section{Effect of substituents $(R 1, R 2)$ on the thermodynamic variable values}

We examine now the effect of R1 and R2 moieties linked to the pyrazolic nitrogen towards thermodynamic variables values. As can be seen from Figures 3-5, the obtained results show a difference of standard enthalpy, heat capacity and entropy variables between the two pairs of compounds $(\mathbf{1}, \mathbf{2})$ and $(\mathbf{3}, \mathbf{4})$. However, there is a smaller difference between the elements of the pairs on the thermodynamic calculated properties.

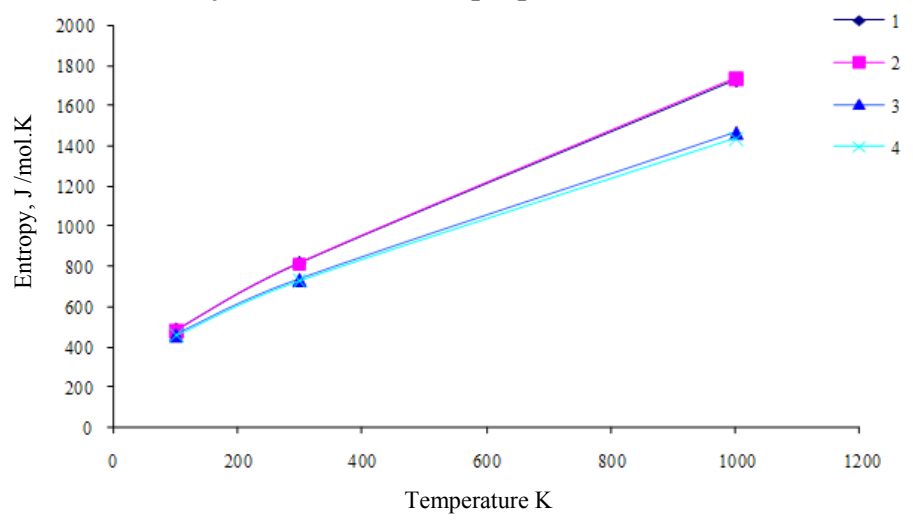

Figure 3. Entropy in $\mathrm{J} \mathrm{mol}^{-1} \mathrm{~K}^{-1}$ of compounds 1-4

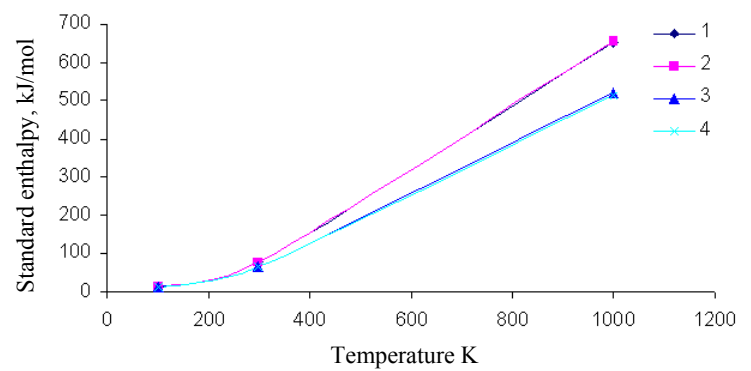

Figure 4. Standard enthalpy in $\mathrm{kJ} \mathrm{mol}^{-1}$ of compounds 1-4

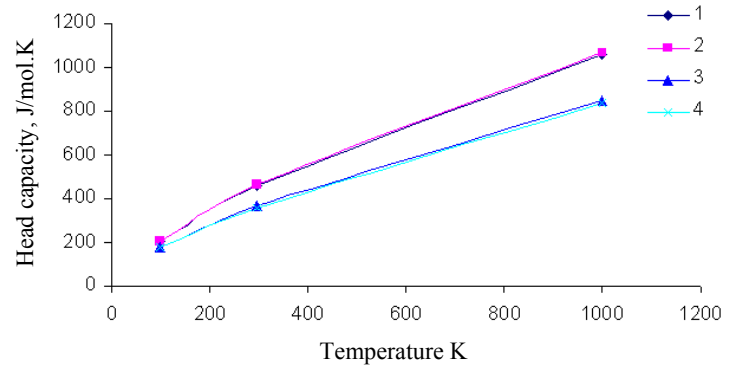

Figure 5. Heat capacity in $\mathrm{J} \mathrm{mol}^{-1} \mathrm{~K}^{-1}$ of compounds 1-4 
Among these $C, C$-linked bipyrazoles, the first pair $(\mathbf{1}, \mathbf{2})$ has the greatest variable values than the second pair $(3,4)$. Two groups of compounds will be distinguished. Case where both two pyrazoles are $N$-aryled: the replacement of the nitro withdrawing moiety in $\mathbf{1}$ by a mesomeric effect donating group such as amino in $\mathbf{2}$ increases at room temperature $(298.15 \mathrm{~K})$ the standard enthalpy of $0.31 \mathrm{~kJ} \mathrm{~mol}^{-1}$ and heat capacity of $3.92 \mathrm{~J} \mathrm{~mol}^{-1} \mathrm{~K}^{-1}$. But the entropy decreases with a value of $0.61 \mathrm{~J} \mathrm{~mol}^{-1} \mathrm{~K}^{-1}$. These minor differences will be probably associated to the dominance of the conjugation phenomenon induced by the phenylic moiety linked to the pyrazolic ring in two $N$-aryl compounds $(\mathbf{1}, \mathbf{2})$. The case where one single pyrazol is $N$-substituted: Results show that compound $\mathbf{3}$ has a higher thermodynamic properties than the $C, C$-linked bipyrazol 4. At room temperature $(298.15 \mathrm{~K})$, the increasing values are respectively $0.25 \mathrm{~kJ} \mathrm{~mol}^{-1}, 6.92 \mathrm{~J} \mathrm{~mol}^{-1} \mathrm{~K}^{-1}, 10.69 \mathrm{~J} \mathrm{~mol}^{-1} \mathrm{~K}^{-1}$ for the standard enthalpy, entropy and heat capacity. These differences may be justified by the type of R1 group attractive effect linked to the pyrazolic ring, electron-donating in $\mathbf{4}$ and electron-withdrawing in 3 . Besides the conjugation phenomenon absent in $4(\mathrm{R} 1=$ $\left.\mathrm{CH}_{2} \mathrm{CO}_{2} \mathrm{Et}\right)$ and present in $3\left(\mathrm{R} 1=\mathrm{p}-\mathrm{NO}_{2}-\mathrm{C}_{6} \mathrm{H}_{4}-\right)$ explains also the results. On the other hand the bis $\mathrm{N}$-arylation in compound 1 has resulted in increases relative to the mono $\mathrm{N}$-aryl compound 3 in $20 \%$ of standard enthalpy, $11 \%$ of entropy and $24 \%$ of heat capacity.

\section{Conclusion}

In this work we have synthesized and characterized a new $C, C$-linked bipyrazol compound 1,1'-di(4-aminophenyl)-5,5'-diisopropyl-3,3'-bipyrazole. Theoretical calculations carried out with the AM1 level of theory using the GAUSSIAN 03 indicate that the diamine (2) and dinitro (1) compounds present similar thermodynamic properties. The bis $N$-aryled $C, C$ linked bipyrazoles have a higher standard enthalpy, entropy and heat capacity values than the mono $\mathrm{N}$-substituted compounds.

\section{References}

1. El-Khawas E S M and Bistawroos A E Alexandria, J Pharm Chem., 1990, 4, 77.

2. Cuadro A, Elguero J and Navarro P, Chem Pharm Bull.,1985, 33, 2535-2540.

3. Tsuboi S, Moriie K, Hatsutori Y, Wada K, Sone S, Oohigata T and Ito A, Jpn Kokai Tokkyo Koho, 1994, JP 06184114 [Chem Abstr., 1995, 122, 105875].

4. Hartfiel U, Dorfmeister G, Franke H, Geisler J, Johann G and Rees R, Eur Pat Appl., 1993, EP 542388 [Chem. Abstr., 1993, 119, 180774].

5. Das N B and Mittra A S, J India Chem Soc., 1978, 55, 829-831.

6. Touzani R, Ramdani A and El Kadiri S, Int J Phys Sci., 2009, 4, 906-912.

7. Bouabdallah I, Touzani R, Zidane I, Ramdani A and Radi S, Arkivoc, 2006, xii, 138-144.

8. Bouabdallah I, Zidane I, Touzani R, Hacht B and Ramdani A, Arkivoc, 2006, xi , 59-65.

9. Bouabdallah I, Ramdani A, Zidane I, Touzani R, Eddike D, Radi S and Haidoux A, $J$ Mar Chim Heterocycl., 2004, 3, 39-44.

10. El Kodadi M, Malek F, Ramdani A, Eddike D, Tillard M and Belin C, J Mar Chim Heterocycl., 2004, 3, 45-52.

11. Tebbji K, Aouniti A, Benkaddour M, Oudda H, Bouabdallah I, Hammouti B and Ramdani A, Prog Org Coat., 2005, 54(3), 170-174;

DOI:10.1016/j.porgcoat.2005.06.001

12. Bouabdallah I, Touzani R, Zidane I and Ramdani A, Cat Commun., 2007, 8(4), 707-712; DOI:10.1016/j.catcom.2006.08.034

13. Bouabdallah I, Ait M'Barek L, Zyad A, Ramdani A, Zidane I and Melhaoui A, Nat Prod Res., 2006, 20(11), 1024-1030; DOI:10.1080/14786410600921441 
14. Bouabdallah I, Touzani R, Zidane I, Ramdani A and Radi S, Arkivoc, 2006, xiv, 46-52.

15. Bouabdallah I, Zidane I, Hacht B, Ramdani A and Touzani R, J Mater Environ Sci., 2010, 1, 20-24.

16. Bouabdallah I, Touzani R, Zidane I and Ramdani A, J Mar Chim Heterocycl., 2007, 6, 21-25.

17. Tebbji K, Aouinti A, Attayibat A, Hammouti B, Oudda H, Benkaddour M, Radi S and Nahle A, Ind J Chem Tech., 2011, 18(3), 244-253.

18. Bouabdallah I, Ait M'Barek L, Zyad A, Ramdani A, Zidane I and Melhaoui A, Nat Prod Res., 2007, 21(4), 298-302; DOI:10.1080/14786410701192801

19. Radi S, Attayibat A, Ramdani A and Bacquet M, Eur Pol J., 2008, 44(10), 3163 3168; DOI:10.1016/j.eurpolymj.2008.07.021

20. Malek F, Ramdani A, Zidane I and Radi S, J App Poly Sci., 2007, 104(6), 3967-3972; DOI:10.1002/app.26211

21. Bouabdallah I, Zidane I, Touzani R, Ramdani A, Jalbout A F and Trzaskowski B, Molbank, 2006, M490-M491; DOI:10.3390/M490

22. Frisch M J, et al., GAUSSIAN 03, Revision A.1, Frisch M J et al., Gaussian, Inc., Pittsburgh PA, 2003.

23. Foresman J B and Frisch Æ, Exploring Chemistry with Electronic Structure Methods, $2^{\text {nd }}$ Edition, Gaussian, INC, Pittsburgh, PA, 1996.

24. Linstrom P J and Mallard W J, Eds., NIST Chemistry WebBook, NIST Standard Reference Database Number 69, July 2001, National Institute of Standards and Technology, Gaithersburg MD, 20899 (http://webbook.nist.gov).

25. Jalbout A F, Solimannejad M and Labonowski J K, Chem Phys Lett., 2003, 379, 503 506; DOI:10.1016/j.cplett.2003.06.002

26. Jalbout A F, Jiang Z-Y, Quasri A, Jeghnou H, Rhandour A, Dhamelincourt M C, Dhamelincourt P and Mazzah A, Vib Spect., 2003, 33, 21-30.

27. Jalbout A F, Nazara F and Turker L, J Mol Struct., 2004, 627, 1-21.

28. Bouabdallah I, Zidane I, Touzani R, Ramdani A, Jalbout A F and Trzaskowski B, $J$ Mar Chim Heterocycl., 2007, 6, 26-31. 